\title{
Association Between Ambient Air Pollution and Multiple Sclerosis: a Systemic Review and Meta-Analysis
}

\author{
Chao Tang \\ Anhui Medical University \\ Qing-Ru Li \\ Anhui Medical University \\ Yan-Mei Mao \\ Anhui Medical University \\ Yuan-Rui Xia \\ Anhui Medical University \\ Heng-Sheng Guo \\ Anhui Medical University \\ Jun-Ping Wang \\ Anhui Medical University \\ Zong-Wen Shuai \\ Anhui Medical University \\ Dong-Qing Ye ( $\nabla$ ydqahmu@126.com) \\ Anhui Medical University https://orcid.org/0000-0001-6604-9614
}

\section{Research Article}

Keywords: Air pollution, Multiple sclerosis, Autoimmune disease, Neurodegeneration disease, Meta-analysis

Posted Date: March 9th, 2021

DOI: https://doi.org/10.21203/rs.3.rs-212139/v1

License: @ (i) This work is licensed under a Creative Commons Attribution 4.0 International License. Read Full License 


\section{Abstract}

The effects of air pollutants on autoimmune diseases are gaining increasing attention. At present, no studies have conducted systemic review and metaanalysis on ambient air pollution and multiple sclerosis (MS). In this paper, literature was collected in order to explore whether there was a connection between air pollutants and MS or not. Through electronic literature search, literature related to our research topic was collected in Cochrane Library, Embase and Pubmed till August 18, 2020 according to certain criteria. Pooled risk estimate and 95\% confidence intervals (95\% $\mathrm{Cl}$ ) were calculated by random-effect model analysis. After removing copies, browsing titles and abstracts and reading full text, 6 studies were finally included. The results showed that only particulate matter (PM) with aerodynamic diameter $\leq 10$ (PM10) was related to MS (pooled $\mathrm{HR}=1.058,95 \% \mathrm{Cl}=1.050-1.066$ ), and no correlation was found between other pollutants and MS. There was no publication bias, and the heterogeneity analysis results were stable. PM is correlated with the disease MS, while other pollution is not connected with MS. More literature results need to be included to meta-analysis results for further study.

\section{Introduction}

Multiple sclerosis (MS) is one of autoimmune diseases with different characteristics of inflammatory. MS is accompanied by central nervous system (CNS) chronic demyelinating, which is featured by dysfunction of the nervous system, neurodegeneration and the lack of central nervous system recovery mechanism (Waubant et al. 2019; Lazibat et al. 2018). Most commonly seen in people between the ages of 20 and 40 , MS can cause symptoms including sensory, visual, cognitive and coordination problem (Bai L et al. 2018).

The incidence of MS is getting higher and higher (Browne et al. 2014), however, etiology of MS is largely unknown. Evidence has suggested that many factors such as environment, heredity, and immune adjustment participated in their pathogenesis (Zhao CN et al. 2019). Environmental risk factors such as epstein-barr virus, humane herpes virus (HHV), sun exposure/vitamin D, tobacco smoking serve as affecting the susceptibility to MS (Lauer K et al. 2010). And there is growing concern that air pollution such as suspended particulate matters (PM) with aerodynamic diameter $\leq 10$ (PM10) and < 2.5 microns (PM2.5), nitrogen dioxide $\left(\mathrm{NO}_{2}\right)$, sulfur dioxide $\left(\mathrm{SO}_{2}\right)$, ozone (03) and carbon monoxide (CO) play an important role in neurodegenerative diseases such as parkinson's disease and multiple sclerosis (Liu et al. 2016; Lemprière et al. 2020; Ashtari et al. 2018). When exposed to air pollutant, airway tissue is not only the interface between air and blood, but may also have the ability to transform air pollutant such as PM and presented them to immunocompetent cell as antigens, triggering an inflammatory response in the lungs and releasing inflammatory cytokines, leading to increased levels throughout the body (Waubant et al. 2019; Jaakkola et al. 2005). Exposure to air pollution can enhance the autoimmune response, local and systemic inflammatory response by affecting immune cell regulation, the secretion of cytokines associated with the inflammatory response and local inflammation (Zhao CN et al. 2019). Air pollution contains mixture of metals, nitrates, sulfates, polycyclic aromatic hydrocarbons (PAHs), dioxins and other adsorbent organic compounds, and these ingredients can trigger the inflammatory signals and have neurotoxicity, which can lead to the degeneration of nerve function and increase the risk of development of MS (Segalet al. 2018; O'Driscoll et al. 2019). In the pathogenesis of MS disease, oxidant production is a major biological effect of tissue damage, local and systemic inflammatory responses. Both direct components of air pollution and host responses to air pollution can cause oxidative stress and neurodystrophy (Gawda et al. 2017).

However, epidemiological evidence supporting the role of air pollutants in the pathogenesis of MS is limited, and the results of epidemiological studies on the air pollutants and MS are inconsistent. For example, in a retrospective study of monthly MS recurrence data from high-risk areas of MS in southwestern Finland from 1985 to 1999, PM10, acidic gases and CO was significantly correlated with MS relapse (Oikonen et al. 2003). A study of MS cases from 2003 to 2013 in Tehran, Iran also showed that PM10, SO2, NO2 and NOx exposure of MS cases was significantly different from control (Heydarpour et al. 2014). But some other studies revealed that no significant association was found based on the current research data (Bai L et al. 2018; Yuchi et al. 2020; Jeanjean et al. 2018). Thus, it is quite important to understand the effect of environmental pollutants to MS. It will help studying the mechanism of disease, determining the correlation between air pollutant exposure, incidence and clinical expression. And it will provide possible targets for the prevention and treatment of MS disease, and provide reference for setting air pollutant standards, which is of significance for the formulation of public health policy.

Recent reviews have focused on studies of air pollutants and the risk of development of MS, but as far as our information goes, no research has metaanalyzed this important field. Our research attempt to quantitatively synthesize the available epidemiological evidence and analyze the pooled effect of air pollutants on MS.

\section{Materials And Methods}

\section{Publication Retrieval}

The research literature was summarized through the electronic retrieval of the literature database and the review of the bibliography of all correlative papers. Cochrane Library, Web of Science and PubMed databases were used for systematic literature retrieval. We collected the literature up to August 18, 2020. The keywords were put into use as follow: ("air pollution" OR "particulate" OR "fine particle" OR "inhalable particle" OR "PM10" OR "fine particulate matter" OR "particulate matter" OR "PM2.5" OR "sulfur dioxide" OR “SO2" OR "nitrogen dioxide" OR "NO2" OR "carbon monoxide" OR "O3" OR "ozone") AND "multiple sclerosis". The recruited data were not limited by race and country, and language was limited to English. Only full-text paper was included in the analysis and meeting or conference abstracts were excluded. 
After removing duplicates, the titles and abstracts were screened independently by two investigators to evaluate whether they were eligible or potentially eligible literature or not. Through browsing, we selected literature with research topics about air pollutants and MS, and obtained the full text as potentially eligible articles for research purposes in order to further evaluate. If there were any differences between two investigators' screening results, differences would then be discussed together with a third investigator to meet an agreement. When dealing with the retrieved full text literature, we considered a study should include in this meta-analysis if it met the criteria as follow: (a) the study used epidemiological studies including casecrossover design, cohort study or case-control study to study the connection between the risk of development of MS and ambient air pollutants (PM2.5, PM10, PM2.5-10, CO, SO2, NO2, 03, NOx, et al.) (b) air pollution must be outdoor (ambient, including traffic-related), non-accidental exposure to outdoor air pollutants did not meet inclusion criteria.

Literature was excluded if it met criteria below: (a) hypothesis, case reports, review articles, letter to editor comments, case reports, animal studies; (b) studies available only in abstract form; (c) original papers did not report the risk estimate (hazard ratio (HR), relative risk (RR) or odds ratio (OR)) and 95\% confidence intervals $(95 \% \mathrm{Cl})$ with a quantified increment of pollutants exposure (ppb, ppm, $\mu \mathrm{g} / \mathrm{m} 3$ or $\mathrm{mg} / \mathrm{m} 3)$ ), or did not give proper data which can calculate the $\mathrm{OR}, \mathrm{RR}$ or $\mathrm{HR}$ and $95 \% \mathrm{Cl}$. If there were different reports on the same study, we selected the latest one with a larger sample size. The flow diagram of literature searching and selection process was presented in Figure 1.

\section{Data extraction and quality evaluation}

The data was extracted from eventually included studies independently by two investigators. The following information from the eligible articles were extracted: first author and published year, study region, study design, time of study period, population characteristic, MS characteristic, disease criteria for MS, air pollution exposure, measurement of ambient air pollution exposure, reported fully adjusted effect size estimates (95\% $\mathrm{Cl}$ ) and confounding factors. In the event of discrepancies, decision was reached to an agreement by the third investigator. Considering air pollutant variables may highly correlated, we extracted and integrated all the HRs, ORs, or RRs after adjusting for multiple confounding variables, and all the HRs, ORs, or RRs were based on single-pollutant models to assess the risk of different air pollutants to MS.

Newcastle - Ottawa Quality Assessment Scale (NOS) was used for evaluating case-control and cohort studies included in our research, and standardized quality assessment score was made (Wu et al. 2016).

\section{Meta-analysis and statistical analysis}

The effect estimates in each primary resource which was stated by authors as "fully adjusted covariates" were synthesized in our present study. Since the incidence of MS in the population were low, we considered that ORs and RRs reported in the original papers can be approximately equivalent to HRs (Cheng et al. 2019). Since the risk estimate (ORs, RRs and HRs) and their $95 \% \mathrm{Cls}$ of the association between ambient air pollution and MS was calculated with different pollutant concentrations increase, risk estimate were standardized to per $10 \mu \mathrm{g} / \mathrm{m}^{3}$ of PM2.5, PM2.5-10 and PM10 exposure, per $1 \mu \mathrm{g} / \mathrm{m}^{3}$ of $\mathrm{C} 6 \mathrm{H} 6$ exposure, per $50 \mu \mathrm{g} / \mathrm{m}^{3}$ of $\mathrm{CO}$ exposure, and per $10 \mathrm{ppb}$ of 03 and NO2 exposure. We converted original reported risk estimate such as HRs to standardized HRs by using the formula:

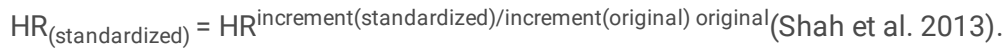

To evaluate heterogeneity across included studies, we used Cochrane $\mathrm{Q}$ test, the chi-square test. To estimate the degree of heterogeneity in this metaanalysis, we used the method $\left(\mathrm{I}^{2}=[(\mathrm{Q}-\mathrm{df}) / \mathrm{Q}] \times 100 \%\right)$ (Huang et al. 2016). If the $\mathrm{Q}$ test result was $\mathrm{P} \otimes 0.05$ or value of $\mathrm{P}^{2} \nabla 50 \%$, studies were considered to have low heterogeneity and the fixed-effect model would be chosen to apply. If the Q test result was $P \otimes 0.05$, studies were considered to have heterogeneity. The value of $\mathrm{I}^{2}$ between $50 \%$ and $75 \%$, over $75 \%$, studies were considered to have moderate heterogeneity, highly heterogeneous, respectively, and under these circumstances, the random-effect model would be used instead of the fixed-effect model for further analysis. Begg's test and Egger's linear regression test was put into use to estimate the potential publication bias. Sensitivity analysis was also performed by removing the literature one by one in order to evaluate the stability and reliability of the studies. The Stata 12.0 software was utilized throughout all data analysis. Research followed the recommendations of Preferred Reporting Items for Systematic Reviews and Meta-Analysis (PRISMA) guidelines (Moher et al. 2010).

\section{Results}

\section{Search Results and Literature Characteristics}

In the current study, literature searching was conducted in Embase, Pubmed and the Cochrane library, and a total of 491 relevant studies were searched. After removing copies (102), titles and abstracts were browsed for left 389 studies. 336 studies were excluded through preliminary screening. Next, 35 studies were selected for further screening, the reviews, letters and the original studies with data reported could not be used for analysis were excluded. 6 studies finally met the pre-set inclusion and exclusion criteria, and was brought into this meta-analysis (Bai L et al. 2018; Yuchi et al. 2020; Jeanjean et al. 2018; Chen et al. 2017; Palacios et al. 2017; Angelici et al. 2016)

Among the 6 included studies, original data were sampled from 4 countries. They belong to Europe and North America. 4 studies were sampled from North America (3 of them from Canada and 1 from US), 2 studies were sampled from Europe (France and Italy). Most studies contained more than one kind of pollutant, including gaseous or particulate. There were 1 case-crossover study, 1 nested case-control study and 4 cohort studies. With the 
exception of one study, which lasted for four years, all the other studies lasted more than eight years, and some lasted longer. Details of the literature characteristics were presented in Table 1, 2. Followed by literature quality evaluation scale, the Newcastle-Ottawa Scale (NOS), 5 studies clearly defined cases, one was unclear. In case-control studies, cases were collected continuously and representative, and cases and controls were comparable. In most cohort studies, exposed cohort and non-exposed cohort were comparative. A standardized quality evaluation scores by NOS was shown in Table 1, Table s1.

\section{Relationship between air pollutants and MS}

Results of the 6 included studies reporting the risk estimate of the association between air pollution and MS were quantitatively synthesized (4 on PM2.5, 5 on PM10, 2 on PM2.5-10, 4 on NO2, 2 on $\mathrm{CO}, 3$ on 03,2 on $\mathrm{C} 6 \mathrm{H6}$, and 2 on road proximity). All air pollutant data in studies included in our research were quantitative data, and the converted data of MS risk synthesized for meta-analysis was shown in Table S2. From our analysis, PM10 was found to be significantly associated with MS development, with the pooled effect size of HR $(95 \% \mathrm{Cl})$ per $10 \mu \mathrm{g} / \mathrm{m} 3$ exposure increase was 1.058 (1.050-1.066). PM2.5, PM2.5-10, C6H6, CO, NO2, 03 and road proximity with distance from major road <50m were found no statistically significant effect on MS development. The pooled effect size of HR $(95 \% \mathrm{Cl})$ of MS per $10 \mu \mathrm{g} / \mathrm{m} 3 \mathrm{PM} 2.5$ exposure increase was 0.977 (0.705-1.353). The pooled effect size of HR $(95 \% \mathrm{Cl})$ of MS per $10 \mu \mathrm{g} / \mathrm{m} 3 \mathrm{PM} 2.5-10$ exposure increase was $1.035(0.791-1.355)$. The pooled effect size of HR (95\% Cl) of MS per $1 \mu \mathrm{g} / \mathrm{m} 3 \mathrm{C} 6 \mathrm{H} 6$ exposure increase was 1.006 (0.947-1.069). The pooled effect size of HR (95\%Cl) of MS per $50 \mu \mathrm{g} / \mathrm{m} 3 \mathrm{CO}$ exposure increase was 0.998 (0.951-1.047). The pooled effect size of HR $(95 \% \mathrm{Cl})$ of MS per $10 \mathrm{ppb}$ NO2 exposure increase was $1.014(0.937-1.098)$. The pooled effect size of HR (95\%Cl) of $\mathrm{MS}$ per $10 \mathrm{ppb} 03$ exposure increase was 1.047 (0.952-1.151). And the pooled effect size of HR $(95 \% \mathrm{Cl})$ of MS living distance from major road $<50 \mathrm{~m}$ was 1.176 (0.838-1.649). The overall effect size of each pollutants on MS was illustrated in Figure 2, 3.

\section{Sensitivity Analyses and Publication Bias}

Generally, it was considered that funnel plot is not a reliable way to investigate publication bias under the circumstance that fewer than 10 studies were included (Cheng et al. 2019). Thus, since our study included only 6 studies, we used Egger's test and Begg's test to evaluate publication bias for each pollutant (Table 3). From the result of our analysis, there was no publication bias for any of the pollutants based on the statistical evidence.

A sensitivity analysis was used to evaluate the reliability of the pooled HRs in our present analysis. The stability of PM2.5 and PM10 was evaluated by removing one study at a time considering the numbers of included studies. The pooled results of PM10 (HR=1.058, 95\% Cl: $1.050-1.066)$ ) did not change obviously when excluded the study conducted in Lombardy, Italy (Angelici et al. 2016) (HR=1.039, 95\%Cl: 1.013-1.067), the study conducted in US Nurses Health Study (NHS, NHS II) (Palacios et al. 2017) (HR=1.058, 95\%Cl: 1.050-1.066), and the study conducted in Strasbourg, France (Jeanjean et al. 2018) (HR=1.060, 95\%Cl: 1.051-1.069). In the sensitivity analysis of PM2.5, the pooled results of PM2.5 (HR=0.977, 95\%Cl: $0.705-1.353)$ ) did not change obviously when excluded the study conducted in Vancouver, Canada (Yuchi et al. 2020) (HR= 0.946, 95\%Cl: 0.731-1.225), the study conducted in Ontario, Canada (Bai L et al. 2018) (HR= 1.058, 95\%Cl: 0.540-2.070), and the study conducted in US Nurses Health Study (NHS, NHS II) (Palacios et al. 2017) $(\mathrm{HR}=1.374,95 \% \mathrm{Cl}: 0.388-4.868)$.

\section{Discussion}

For all we know, some articles have discussed the correlation between air pollutants and autoimmune diseases, such as systemic lupus erythematosus (SLE) (Zhao et al. 2019; Jung et al.2019), rheumatoid arthritis (RA) (Alsaber et al. 2020; Di et al. 2019). Some studies have also conducted systematic review and meta-analysis on air pollution and neurological diseases (Cheng et al. 2019; Fu et al. 2019). However, there was no literature meta-analysis the association of air pollution exposure and MS. Our paper attempts to include 6 articles to analyze the effects of air pollutants on MS. Results from our meta-analysis suggest that except that PM10 is related to MS, other pollutants are not related to the MS. The reason may be that the air pollutant level, measurement time and exposure assessment methods were different during the study process, as well as the differences in related measurement methods and established model differences.

The literature on MS included in the analysis were all from developed countries in Europe (Jeanjean et al. 2018; Angelici et al. 2016) and America (Bai L et al. 2018; Yuchi et al. 2020; Chen et al. 2017; Palacios et al. 2017), which may bias the analysis to some extent due to differences in geography, climate and air quality (Witkowska et al. 2016). With the support of more literature, the inclusion of more reliable analysis data from Asian countries and underdeveloped regions will reduce the bias of poor results.

Except for the study region need to be discussed, the time lag effect has been taken into account in the extensive literature on the connection between ambient pollutant exposure and disease. It suggested that there may be a time lag on association between exposure to pollution and causing reactions in the body that affect the progression of the disease (Ritz et al. 2016; Hao et al. 2019). Among the literature on MS summarized in present research, two studies (Jeanjean et al. 2018; Angelici et al. 2016) adopted time-lag model of pollutant exposure, and the rest included literature did not study it. So, in our research, we did not analyze the time lag effect due to the limited number of studies, but we can not deny its potential role.

Considering the connection between air pollutants and autoimmune diseases, we realized that this could be affected by seasonal differences. In a study included in our meta-analysis, it separately analyzed hot season and cold season pollutant model, and found the influence of pollutants to autoimmune diseases varied. In hot season, there is no connection between the pollutants in MS, but in cold season, conversely. The result is similar with a study on COPD (Tsai et al. 2014). It could be observed that the effects of pollutants vary with the seasons. It may be related to the interaction of vegetation coverage, air temperature and humidity in different seasons. From the perspective of seasonal changes, the overall order winter $>$ autumn $>$ spring > 
summer is observed for atmospheric pollution, and the temporal heterogeneity was significant (Sun et al. 2019; Vojinović et al. 2015). Previous studies also shown that seasonal differences in MS were related to seasonal differences in ultraviolet radiation and vitamin D. Worse air pollution may affect the spread of UVB in the surface layer and caused a sharp decline in the body's production of vitamin D (Watad et al. 2017; Gallagher et al. 2019; Pan et al. 2019). All in all, these suggested that when explore the association of MS and ambient air pollution, more attention need to pay to seasons and meteorological factors in the future research. Several other risk factors, such as less sun exposure and viral infections also need to take into account. This provides guidance for future research to study the risk factors and mechanism of MS.

In terms of data sources, some studies come from large cohorts, while others come from national insurance systems with a nationwide file, etc. Bias may arise from differences in the sources of study population. Meanwhile, differences in the acquisition of pollutant exposure data and adoption of pollutant models may also produce bias to some extent. Limited by methods using in original research, we used single-pollutant models to analyze the effect size which could not consider adjustments for collinearity between pollutants and could not fully illustrate the connection of the disease and the overall mixed pollution exposure. However, as the studies we included were all high-quality cohort or case-control studies, the analysis results were of certain reference value in general.

Many studies found that worse air quality was associated with MS, but were not included in our current analysis due to the difference of statistical processing. Cross-sectional studies conducted in Turkey found that the incidence of MS was higher in the city with an iron-and-steel factory than a cleaner city in the same region (Börü et al. 2018; Börü et al. 2020). Similarly, a study also revealed mean annual PM2.5 levels was associated with MS (Corona-Vázquez et al. 2019). A significant correlation was also found in a case-control study of factory exhaust emissions and MS (Lavery et al. 2018). When considering the pediatric MS, a study found Ecological Quality Index (EQI) contributed to pediatric MS (Lavery et al. 2017). The air quality index (AQI) data was found significantly associated with higher expanded disability status scale (EDSS) of MS patients (Ashtari et al. 2018). Earlier studies also suggested that air pollutants may participate in the development of MS (Oikonen et al. 2003; Heydarpour et al. 2014; Gregory et al. 2008). On the other hand, a study explored the relationship between environmental pollution and the aggravation of MS disease, using the increase in the dosage of cortisol as an indicator to illustrate the possible role of air pollution to MS disease and was a new research approach (Faustini et al. 2018).

In our research, PM10 was found associated with the risk of MS. Many studies have attempted to study this correlation from the perspective of molecular and immune mechanism. Particulate pollutant is a complex mixture of several harmful materials. For example, metal aluminum can induce the production of inflammatory signals, disrupt the cellular metabolism, damage mitochondrial function and lead to oxidative stress. In addition, aluminum have neurotoxicity which can lead to neurological impairment and promote the development of MS. Known as aryl hydrocarbon receptor (AHR), PAHs and dioxins regulated pathological T cells of the central nervous system, and atmospheric particles may stimulate T cell differentiation, aggravated the inflammatory immune response and autoimmune diseases (Segal $Y$ et al. 2018; O'Driscoll et al. 2019). Exposure to particulate matter could produce a dose-dependent proinflammatory cytokines, such a TNF-a, IL-6 and IL-12p40, and it could lead to a highly inflammatory response by contacting to lipopolysaccharide (LPS) by activated macrophage (Gawda et al. 2018). And exposure to particulate matter had a strong effect on redox biochemistry (Mikrut et al. 2018). Studies of the mechanism suggest that air pollutants have a potential role in the progression of MS disease, and epidemiological studies are needed to obtain evidence.

Several shortcomings in our study need to be acknowledged. Firstly, the studies included in our analysis were all observational studies, thus, there may be some bias existing. Secondly, due to the limitation of literature quantity, the amount of studies included in our analysis was small. It needs to update when more research results about this title published articles.

Despite these limitations, this study has several advantages. Firstly, the study year span and sample size in our meta-analysis were both large, which makes conclusions reliable. Secondly, we did not detect any publication bias, that is to say, the results we included may be unbiased, and the results of the sensitivity analysis indicated that our findings were stable. Thirdly, this is the first meta-analysis of air pollutants with MS, which provide a relatively credible conclusion and a direction for further research.

\section{Conclusion}

As a whole, from our current analysis, only PM10 is related to the risk of development of MS, while NO2, 03, CO and PM2.5 are not significantly associated with MS. Restricted by the amount of literature, more research needs to be devoted to this topic to reveal the exact role of air pollutants in the progression of MS.

\section{Declarations}

Ethics approval and consent to participate Not applicable.

Consent for publication Not applicable.

Availability of data and materialsThe datasets used and/or analysed during the current study are available from the corresponding author on reasonable request.

Competing interests The authors declare that they have no competing interestst.

Funding imformation This work was supported by grants from the National Natural Science Foundation of China (Code: 8187120580 ) 
CH made formal analysis, conceptualization and original Draft. QRL made software analysis, and writing original draft. YMM made validation, investigation and search resources. YRX made investigation and figure visualization. HSG made data curation. JPW made data verification. ZWS reviewed the manuscript. DQY reviewed the manuscript and acquire funding.

\section{Acknowledgements}

Thanks for the tutor's careful guidance and help from the fellows in research group.

\section{References}

1. Alsaber A, Pan J, Al-Herz A, Alkandary DS, Al-Hurban A, Setiya P, On Behalf Of The Krrd Group (2020). Influence of Ambient Air Pollution on Rheumatoid Arthritis Disease Activity Score Index. Int J Environ Res Public Health 17(2):416. https://doi.org/10.3390/ijerph17020416.

2. Angelici L, Piola M, Cavalleri T, Randi G, Cortini F, Bergamaschi R, Baccarelli AA, Bertazzi PA, Pesatori AC, Bollati V. Effects of particulate matter exposure on multiple sclerosis hospital admission in Lombardy region, Italy (2016). Environ Res 145:68-73.

https://doi.org/10.1016/j.envres.2015.11.017.

3. Ashtari F, Esmaeil N, Mansourian M, Poursafa P, Mirmosayyeb O, Barzegar M, Pourgheisari H (2018). An 8-year study of people with multiple sclerosis in Isfahan, Iran: Association between environmental air pollutants and severity of disease. J Neuroimmunol. 319:106-111. https://doi.org/10.1016/j.jneuroim.2018.02.019.

4. Bai L, Burnett RT, Kwong JC, Hystad P, van Donkelaar A, Brook JR, Tu K, Copes R, Goldberg MS, Martin RV, Murray BJ, Kopp A, Chen H. (2018). Longterm exposure to air pollution and the incidence of multiple sclerosis: A population-based cohort study. Environ Res. 166:437-443. https://doi.org/10.1016/j.envres.2018.06.003.

5. Börü ÜT, Bilgiç AB, Köseoğlu Toksoy C, Yılmaz AY, Tasdemir M, Sensöz NP, Öztop Çakmak Ö, Duman A, Bölük C. (2018). Prevalence of multiple sclerosis in a Turkish city bordering an iron and steel factory. J Clin Neurol 14:234-241. https://doi.org/10.3988/jcn.2018.14.2.234.

6. Türk Börü Ü, Bölük C, Taşdemir M, Gezer T, Serim VA. Air pollution, a possible risk factor for multiple sclerosis. (2020). Air pollution, a possible risk factor for multiple sclerosis. Acta Neurol Scand 141(5):431-437. https://doi.org/10.1111/ane.13223.

7. Browne P, Chandraratna D, Angood C, Tremlett H, Baker C, Taylor BV, Thompson AJ. (2014). Atlas of multiple sclerosis 2013: a growing global problem with widespread inequity. Neurology. 83(11):1022-1024. https://doi.org/10.1212/WNL.0000000000000768

8. Corona-Vázquez T, Flores Rivera JJ, RodríguezViolante M, Cervantes-Arriaga A. (2019). Air pollution, multiple sclerosis and its relevance to Mexico City. Arch Med Res 50:111-112. https://doi.org/10.1016/j.arcmed.2019.07.003.

9. Chen H, Kwong JC, Copes R, Tu K, Villeneuve PJ, van Donkelaar A, Hystad P, Martin RV, Murray BJ, Jessiman B, Wilton AS, Kopp A, Burnett RT. (2017). Living near major roads and the incidence of dementia, Parkinson's disease, and multiple sclerosis: a population-based cohort study. Lancet 389(10070):718-726. https://doi.org/10.1016/S0140-6736(16)32399-6.

10. Hu CY, Fang Y, Li FL, Dong B, Hua XG, Jiang W, Zhang H, Lyu Y, Zhang XJ. (2019). Association between ambient air pollution and parkinson's disease: systematic review and meta-analysis. Environ Res. 168:448-459. https://doi.org/10.1016/j.envres.2018.10.008.

11. Di D, Zhang L, Wu X, Leng R. (2020). Long-term exposure to outdoor air pollution and the risk of development of rheumatoid arthritis: A systematic review and meta-analysis. Semin Arthritis Rheum 50:266-275. https://doi.org/10.1016/j.semarthrit.2019.10.005.

12. Faustini A, Renzi M, Kirchmayer U. (2018). Short-term exposure to air pollution might exacerbate autoimmune diseases. Environmental Epidemiology 2(3):e025. https://doi.org/10.1097/EE9.0000000000000025.

13. Fu P, Guo X, Cheung FMH, Yung KKL. (2019). The association between PM exposure and neurological disorders: a systematic review and metaanalysis. Sci Total Environ. 655:1240-1248. https://doi.org/10.1016/j.scitotenv.2018.11.218.

14. Gallagher LG, Ilango S, Wundes A, Stobbe GA, Turk KW, Franklin GM, Linet MS, Freedman DM, Alexander BH, Checkoway H. (2019). Lifetime exposure to ultraviolet radiation and the risk of multiple sclerosis in the US radiologic technologists cohort study. Mult Scler 25:1162-1169. https://doi.org/10.1177/1352458518783343.

15. Gawda A, Majka G, Nowak B, Marcinkiewicz J. (2017). Air pollution, oxidative stress, and exacerbation of autoimmune diseases. Cent Eur J Immunol 42:305-312. https://doi.org/10.5114/ceji.2017.70975.

16. Gawda A, Majka G, Nowak B, Śróttek M, Walczewska M, Marcinkiewicz J. (2018). Air particulate matter SRM 1648a primes macrophages to hyperinflammatory response after LPS stimulation. Inflamm Res 67:765-776. https://doi.org/10.1007/s00011-018-1165-4.

17. Gregory AC 2nd, Shendell DG, Okosun IS, Gieseker KE. (2008). Multiple sclerosis disease distribution and potential impact of environmental air pollutants in Georgia. Sci Total Environ. 396(1):42-51. https://doi.org/10.1016/j.scitotenv.2008.01.065.

18. Hao J, Yang Z, Huang S, Yang W, Zhu Z, Tian L, Lu Y, Xiang H, Liu S. (2019). The association between short-term exposure to ambient air pollution and the incidence of mumps in Wuhan, China: A time-series study. Environ Res. 177:108660. https://doi.org/10.1016/j.envres.2019.108660.

19. Heydarpour P, Amini H, Khoshkish S, Seidkhani H, Sahraian MA, Yunesian M. (2014). Potential Impact of Air Pollution on Multiple Sclerosis in Tehran, Iran. Neuroepidemiology. 43:233-238. https://doi.org/10.1159/000368553. 
20. Huang XL, Zhang L, Duan Y, Wang YJ, Wang J. (2016). Association of pentraxin 3 with autoimmune diseases: a systematic review and metaanalysis. Arch Med Res 47(3):223-231. https://doi.org/10.1016/j.arcmed.2016.05.006

21. Sigaux J, Biton J, André E, Semerano L, Boissier MC. (2019). Air pollution as a determinant of rheumatoid arthritis. Joint bone spine 86(1):37-42. https://doi.org/10.1016/j.jbspin.2018.03.001

22. Jeanjean M, Bind MA, Roux J, Ongagna JC, de Sèze J, Bard D, Leray E. (2018). Ozone, NO and PM are associated with the occurrence of multiple sclerosis relapses. Evidence from seasonal multi-pollutant analyses. Environ Res 163:43-52. https://doi.org/10.1016/j.envres.2018.01.040.

23. Jung CR, Chung WT, Chen WT, Lee RY, Hwang BF. (2019). Long-term exposure to traffic-related air pollution and systemic lupus erythematosus in Taiwan: a cohort study. Sci Total Environ 668:342-349. https://doi.org/10.1016/j.scitotenv.2019.03.018.

24. Lauer K. (2010). Environmental risk factors in multiple sclerosis. Expert Rev Neurother 10(3):421-440. https://doi.org/10.1586/ern.10.7.

25. Lavery AM, Waubant E, Casper TC, Roalstad S, Candee M, Rose J, Belman A, Weinstock-Guttman B, Aaen G, Tillema JM, Rodriguez M, Ness J, Harris Y, Graves J, Krupp L, Charvet L, Benson L, Gorman M, Moodley M, Rensel M, Goyal M, Mar S, Chitnis T, Schreiner T, Lotze T, Greenberg B, Kahn I, Rubin J, Waldman AT. (2018). Urban air quality and associations with pediatric multiple sclerosis. Ann Clin Transl Neurol. 5(10):1146-1153. https://doi.org/10.1002/acn3.616.

26. Lavery AM, Waldman AT, Charles Casper T, Roalstad S, Candee M, Rose J, Belman A, Weinstock-Guttman B, Aaen G, Tillema JM, Rodriguez M, Ness J, Harris Y, Graves J, Krupp L, Benson L, Gorman M, Moodley M, Rensel M, Goyal M, Mar S, Chitnis T, Schreiner T, Lotze T, Greenberg B, Kahn I, Rubin J, Waubant E; U.S. (2017). Examining the contributions of environmental quality to pediatric multiple sclerosis. Mult Scler Relat Disord. 18:164-169. https://doi.org/10.1016/j.msard.2017.09.004

27. Lazibat I, Rubinić Majdak M, Županić S. (2018). Multiple sclerosis: new aspects of immunopathogenesis. Acta Clin Croat 57:352-361. https://doi.org/10.20471/acc.2018.57.02.17.

28. Lemprière S. (2020). Air pollution linked to multiple sclerosis and stroke. Nat Rev Neurol 16(3):127. https://doi.org/10.1038/s41582-020-0322-x.

29. Liu R, Young MT, Chen JC, Kaufman JD, Chen H. (2016). Ambient Air Pollution Exposures and Risk of Parkinson Disease. Environ Health Perspect. 124:1759-1765. https://doi.org/10.1289/EHP135.

30. Mikrut M, Regiel-Futyra A, Samek, et al. (2018). Generation of hydroxyl radicals and singlet oxygen by particulate matter and its inorganic components. Environ Pollut 238:638-646. https://doi.org/10.1016/j.envpol.2018.03.068.

31. Moher D, Liberati A, Tetzlaff J, et al. (2010). Preferred reporting items for systematic reviews and meta-analyses: the PRISMA statement. Int J Surg 8:336-341. https://doi.org/10.1016/j.ijsu.2010.02.007.

32. O'Driscoll CA., Owens LA, Hoffmann EJ, et al. (2019). Ambient urban dust particulate matter reduces pathologic T cells in the CNS and severity of EAE. Environ Res 168:178-192. https://doi.org/10.1016/j.envres.2018.09.038.

33. Oikonen M., Laaksonen M., Laippala P, et al. 2003. Ambient air quality and occurrence of multiple sclerosis relapse. Neuroepidemiology. 22:95-99. https://doi.org/10.1159/000067108.

34. Palacios N, Munger KL, Fitzgerald KC, et al. (2017). Exposure to particulate matter air pollution and risk of multiple sclerosis in two large cohorts of US nurses. Environ Int. 109:64-72. https://doi.org/10.1016/j.envint.2017.07.013.

35. Pan HF, Wang P, Wu GC, et al. (2019). Seasonal variation in systemic lupus erythematosus and rheumatoid arthritis: an ecological study based on internet searches. Autoimmun Rev 18:825-827. https://doi.org/10.1016/j.autrev.2019.06.001.

36. Ritz B, Lee PC, Hansen J, et al. (2016). Traffic-related air pollution and parkinson's disease in Denmark: a case-control study. Environ Health Perspect. 124:351-356. https://doi.org/10.1289/ehp.1409313.

37. Segal Y, Dahan S, Sharif K, et al. (2018). The value of autoimmune syndrome induced by adjuvant (ASIA) - shedding light on orphan diseases in autoimmunity. Autoimmun Rev 17:440-448. https://doi.org/10.1016/j.autrev.2017.11.037.

38. Shah AS, Langrish JP, Nair H, et al. (2013). Global association of air pollution and heart failure: a systematic review and meta-analysis. Lancet 382(9897):1039-1048. https://doi.org/10.1016/S0140-6736(13)60898-3.

39. Sun S, Li LJ, Zhao WJ, et al. (2019). Variation in pollutant concentrations and correlation analysis with the vegetation index in Beijing-Tianjin-Hebei. Huan Jing Ke Xue 40:1585-1593. https://doi.org/10.13227/j.hjkx.201809178.

40. Tsai SS, Chiu HF, Liou SH, et al. (2014). Short-term effects of fine particulate air pollution on hospital admissions for respiratory diseases: a casecrossover study in a tropical city. J Toxicol Environ Health A 77(18):1091-1101. https://doi.org/10.1080/15287394.2014.922388.

41. Vojinović S, Savić D, Lukić S, et al. (2015). Disease relapses in multiple sclerosis can be influenced by air pollution and climate seasonal conditions. Vojnosanit Pregl 72:44-49. https://doi.org/10.2298/vsp140121030v.

42. Watad A, Azrielant S, Bragazzi NL, et al. (2017). Seasonality and autoimmune diseases: the contribution of the four seasons to the mosaic of autoimmunity. J Autoimmun 82:13-30. https://doi.org/10.1016/j.jaut.2017.06.001.

43. Waubant E, Lucas R, Mowry E, et al. (2019). Environmental and genetic risk factors for MS: an integrated review. Ann Clin Transl Neurol. 6:19051922. https://doi.org/10.1002/acn3.50862.

44. Witkowska A, Lewandowska AU, Saniewska D. (2016). Effect of agriculture and vegetation on carbonaceous aerosol concentrations (PM2.5 and PM10) in Puszcza Borecka National Nature Reserve (Poland). Air Qual Atmos Health 9:761-773. https://doi.org/10.1007/s11869-015-0378-8.

45. Wu GC, Liu HR, Leng RX, et al. 2016. Subclinical atherosclerosis in patients with systemic lupus erythematosus: a systemic review and metaanalysis. Autoimmun Rev 15(1):22-37. https://doi.org/10.1016/j.autrev.2015.10.002.

Page 7/14 
46. Yuchi W, Sbihi H, Davies H, et al. (2020). Road proximity, air pollution, noise, green space and neurologic disease incidence: a population-based cohort study. Environ Health 19:8. https://doi.org/10.1186/s12940-020-0565-4.

47. Zhao CN, Mei YJ, Wu GC, et al. (2019). Effect of air pollution on hospital admissions for systemic lupus erythematosus in Bengbu, China: a time series study. Lupus 28:1541-1548. https://doi.org/10.1177/0961203319882503.

48. Zhao CN, Xu Z, Wu GC, et al. (2019). Emerging role of air pollution in autoimmune diseases. Autoimmun Rev 18:607-614.

https://doi.org/10.1016/j.autrev.2018.12.010.

\section{Tables}

Table 1. Characteristics of the original literature about the connection between ambient air pollutants and MS.

\begin{tabular}{|c|c|c|c|c|c|c|c|c|c|c|}
\hline \multirow{2}{*}{$\begin{array}{l}\text { First } \\
\text { author, } \\
\text { year }\end{array}$} & \multirow[t]{2}{*}{ Region } & \multirow{2}{*}{$\begin{array}{l}\text { Study } \\
\text { period }\end{array}$} & \multirow{2}{*}{$\begin{array}{l}\text { Study } \\
\text { design }\end{array}$} & \multirow{2}{*}{$\begin{array}{l}\text { Population } \\
\text { characteristics }\end{array}$} & \multirow{2}{*}{$\begin{array}{l}\text { Number of } \\
\text { all cohort/ } \\
\text { case-control } \\
\text { members }\end{array}$} & \multicolumn{4}{|c|}{ Multiple sclerosis cases } & \multirow[t]{2}{*}{ NOS } \\
\hline & & & & & & Number & $\begin{array}{l}\text { Female } \\
(\%)\end{array}$ & $\begin{array}{l}\text { Mean age } \\
\text { (years) }\end{array}$ & $\begin{array}{l}\text { Inclusion } \\
\text { criteria }\end{array}$ & \\
\hline $\begin{array}{l}\text { Yuchi W, } \\
2020\end{array}$ & $\begin{array}{l}\text { Vancouver, } \\
\text { Canada }\end{array}$ & $\begin{array}{l}\text { 1999.1- } \\
2003.12\end{array}$ & $\begin{array}{l}\text { Nested } \\
\text { case- } \\
\text { control } \\
\text { study }\end{array}$ & $\begin{array}{l}\text { Population Data } \\
\text { British } \\
\text { Columbia } \\
\text { provided } \\
\text { administrative } \\
\text { health data of } \\
\text { the Medical } \\
\text { Services Plan } \\
\text { which is a } \\
\text { mandatory } \\
\text { health } \\
\text { insurance } \\
\text { program }\end{array}$ & 7232 & 658 & NA & NA & $\begin{array}{l}\text { ICD-9 or } \\
\text { ICD-10 }\end{array}$ & 8 \\
\hline $\begin{array}{l}\text { Jeanjean } \\
M, 2018\end{array}$ & $\begin{array}{l}\text { Strasbourg, } \\
\text { France }\end{array}$ & $\begin{array}{l}\text { 2000.1.1 - } \\
\text { 2009.12.31 }\end{array}$ & $\begin{array}{l}\text { Case- } \\
\text { crossover } \\
\text { study }\end{array}$ & $\begin{array}{l}\text { The multiple } \\
\text { sclerosis } \\
\text { network } \\
\text { alSacEP based } \\
\text { in Alsace North- } \\
\text { Eastern region }\end{array}$ & $\begin{array}{l}3408 \\
\text { control days } \\
\text { from } 424 \\
\text { patients }\end{array}$ & 424 & 74.5 & $(30.5 \pm 10.0)$ & $\begin{array}{l}\text { McDonalds' } \\
\text { MS criteria }\end{array}$ & 8 \\
\hline $\begin{array}{l}\text { Bai L, } \\
2018\end{array}$ & $\begin{array}{l}\text { Ontario, } \\
\text { Canada }\end{array}$ & $\begin{array}{l}2001.04 .01- \\
2013.12 .31\end{array}$ & $\begin{array}{l}\text { Cohort } \\
\text { study }\end{array}$ & $\begin{array}{l}\text { The ontario } \\
\text { population } \\
\text { health and } \\
\text { environment } \\
\text { cohort } \\
\text { (ONPHEC) }\end{array}$ & 2824478 & 6200 & 70.7 & $30.7(6.0)$ & $\begin{array}{l}\text { ICD-9CM or } \\
\text { ICD-10 }\end{array}$ & 9 \\
\hline $\begin{array}{l}\text { Chen H, } \\
2017\end{array}$ & $\begin{array}{l}\text { Ontario, } \\
\text { Canada }\end{array}$ & $\begin{array}{l}2001.4- \\
2012\end{array}$ & $\begin{array}{l}\text { Cohort } \\
\text { study }\end{array}$ & $\begin{array}{l}\text { Ontario's } \\
\text { Registered } \\
\text { Persons } \\
\text { Database, a } \\
\text { registry of all } \\
\text { residents who } \\
\text { have ever had } \\
\text { health } \\
\text { insurance. }\end{array}$ & 4372720 & 9247 & $50.2^{a}$ & $35.9(8.7)^{\mathrm{a}}$ & NA & 8 \\
\hline $\begin{array}{l}\text { Palacios } \\
\mathrm{N} \unrhd 2017\end{array}$ & US & $\begin{array}{l}\text { NHS:1988 - } \\
2004.5 .31 \\
\text { NHS } \\
\text { II:1988- } \\
2007.5 .31\end{array}$ & $\begin{array}{l}\text { Cohort } \\
\text { study }\end{array}$ & $\begin{array}{l}\text { The Nurses } \\
\text { Health Study } \\
\text { (NHS) and the } \\
\text { Nurses Health } \\
\text { Study II (NHS II) }\end{array}$ & $\begin{array}{l}\text { NHS: } 121700 \\
\text { NHS } \\
\text { II:116671 }\end{array}$ & $\begin{array}{l}\text { NHS II: } \\
408 \text {, } \\
\text { NHS: } \\
117\end{array}$ & $\begin{array}{l}\text { The } \\
\text { total is } \\
\text { NA }\end{array}$ & $\begin{array}{l}\text { The total is } \\
\text { NA }\end{array}$ & $\begin{array}{l}\text { McDonald } \\
\text { criteria }\end{array}$ & 7 \\
\hline $\begin{array}{l}\text { Angelici } \\
\text { L, } 2016\end{array}$ & $\begin{array}{l}\text { Lombardy, } \\
\text { Italy }\end{array}$ & $2001-2009$ & $\begin{array}{l}\text { Cohort } \\
\text { study }\end{array}$ & $\begin{array}{l}\text { Hospitalizations } \\
\text { linked to MS } \\
\text { events occurred } \\
\text { in } 107 \text { hospitals } \\
\text { located in the } \\
\text { Lombardy, Italy }\end{array}$ & 9419553 & 8287 & 68.61 & $\begin{array}{l}\text { The total is } \\
\text { NA }\end{array}$ & ICD9-CM & 7 \\
\hline
\end{tabular}

ICD, International Classification of Diseases; NA, not available; a: Characteristics for multiple sclerosis cohort, the characteristics for multiple sclerosis cases was not available;

Table 2 Exposure, reported fully adjusted estimate and covariate adjusted of the studies. 


\begin{tabular}{|c|c|c|c|c|c|}
\hline $\begin{array}{l}\text { First } \\
\text { author, } \\
\text { year }\end{array}$ & $\begin{array}{l}\text { Exposure } \\
\text { pollutants }\end{array}$ & Exposure assessment & $\begin{array}{l}\text { Exposure } \\
\text { estimate }\end{array}$ & $\begin{array}{l}\text { Reported } \\
\text { fully } \\
\text { adjusted } \\
\text { estimates } \\
(95 \% \mathrm{Cl})\end{array}$ & Covariates adjusted \\
\hline $\begin{array}{l}\text { Yuchi W, } \\
2020\end{array}$ & $\begin{array}{l}\text { Road } \\
\text { proximity, } \\
\text { PM2.5, } \\
\text { Black } \\
\text { carbon, } \\
\text { NO2, } \\
\text { NO, } \\
\text { Noise, } \\
\text { Greenness }\end{array}$ & $\begin{array}{l}\text { Road proximity:using DMTI road } \\
\text { network with each person's } \\
\text { residence (residential postal } \\
\text { code); } \\
\text { Air pollution: land-use regression } \\
\text { models; } \\
\text { Noise: a noise prediction model; } \\
\text { Greenness: the satellite derived } \\
\text { Normalized Difference } \\
\text { Vegetation Index (NDVI) }\end{array}$ & $\begin{array}{l}\text { PM2.5 ( } \mu \mathrm{g} / \mathrm{m} 3) \text { : } \\
\text { Median:4.1, } \\
\text { Maximum: } 10.2 \\
\text { Minimum:0.6 } \\
\text { IQR:1.5 } \\
\text { Black carbon } \\
\text { ( } \mu \text { g/m3): } \\
\text { Median:1.0, } \\
\text { Maximum: } 5.0 \\
\text { Minimum:0 } \\
\text { IQR:1.3 } \\
\text { NO2 (ppb): } \\
\text { Median:30.1, } \\
\text { Maximum: } 57.6 \\
\text { Minimum:14.4 } \\
\text { IQR:8.0 } \\
\text { No (ppb): } \\
\text { Median:29.6, } \\
\text { Maximum: } 71.3 \\
\text { Minimum:11.0 } \\
\text { IQR:14.5 } \\
\text { Noise(Lden } \\
\text { dB(A)): } \\
\text { Median:60.3, } \\
\text { Maximum: } 82.5 \\
\text { Minimum:36.2 } \\
\text { IQR:5.4 } \\
\text { Greenness } \\
\text { (NDVl): } \\
\text { Median:0.3, } \\
\text { Maximum: } 0.5 \\
\text { Minimum:0.0 } \\
\text { IQR:0.1 }\end{array}$ & 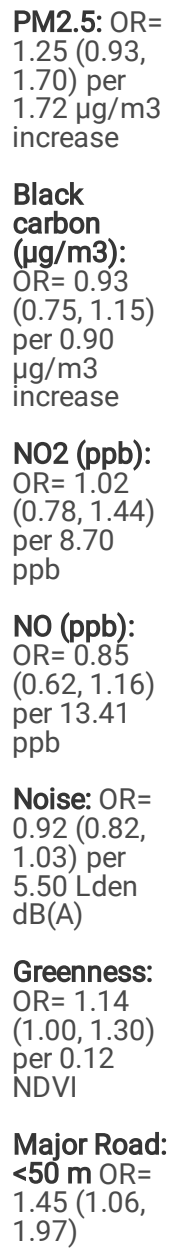 & $\begin{array}{l}\text { Age, sex income, education and comorbidities } \\
\text { including traumatic brain injury, diabetes, } \\
\text { hypertension, stroke, coronary heart disease, } \\
\text { congestive heart failure and arrhythmia }\end{array}$ \\
\hline $\begin{array}{l}\text { Jeanjean } \\
\mathrm{M}, 2018\end{array}$ & $\begin{array}{l}\text { PM10, } \\
\text { N02, } \\
\text { benzene } \\
\text { (C6H6), } \\
\text { O3, } \\
\text { Co }\end{array}$ & $\begin{array}{l}\text { The deterministic ADMS-Urban } \\
\text { air dispersion model was used } \\
\text { considering different } \\
\text { parameters, namely background } \\
\text { pollution measurements, } \\
\text { emissions inventories, } \\
\text { meteorological data but also } \\
\text { land } \\
\text { use or surface roughness } \\
\text { (Atmospheric Dispersion } \\
\text { Modeling System) }\end{array}$ & 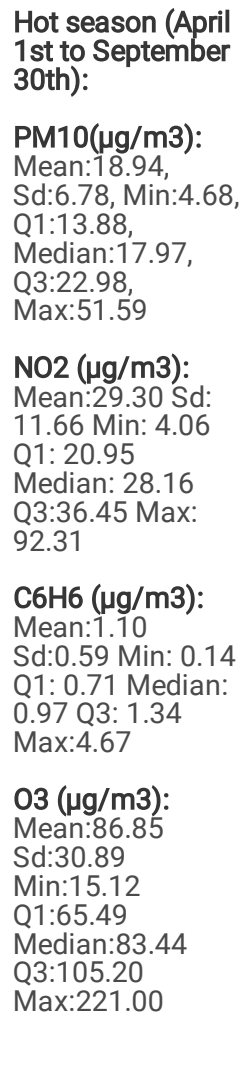 & 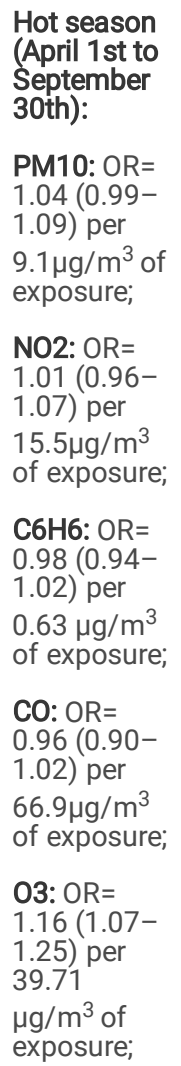 & $\begin{array}{l}\text { time-varying confounders, meteorological } \\
\text { parameters (daily temperature, relative humidity } \\
\text { and atmospheric pressure), daily pollen counts, } \\
\text { Weekly influenza-like case count, holidays, which } \\
\text { could potentially influence industrial activities } \\
\text { and road traffic, as well as stress level, fatigue or } \\
\text { being at home or not. }\end{array}$ \\
\hline
\end{tabular}




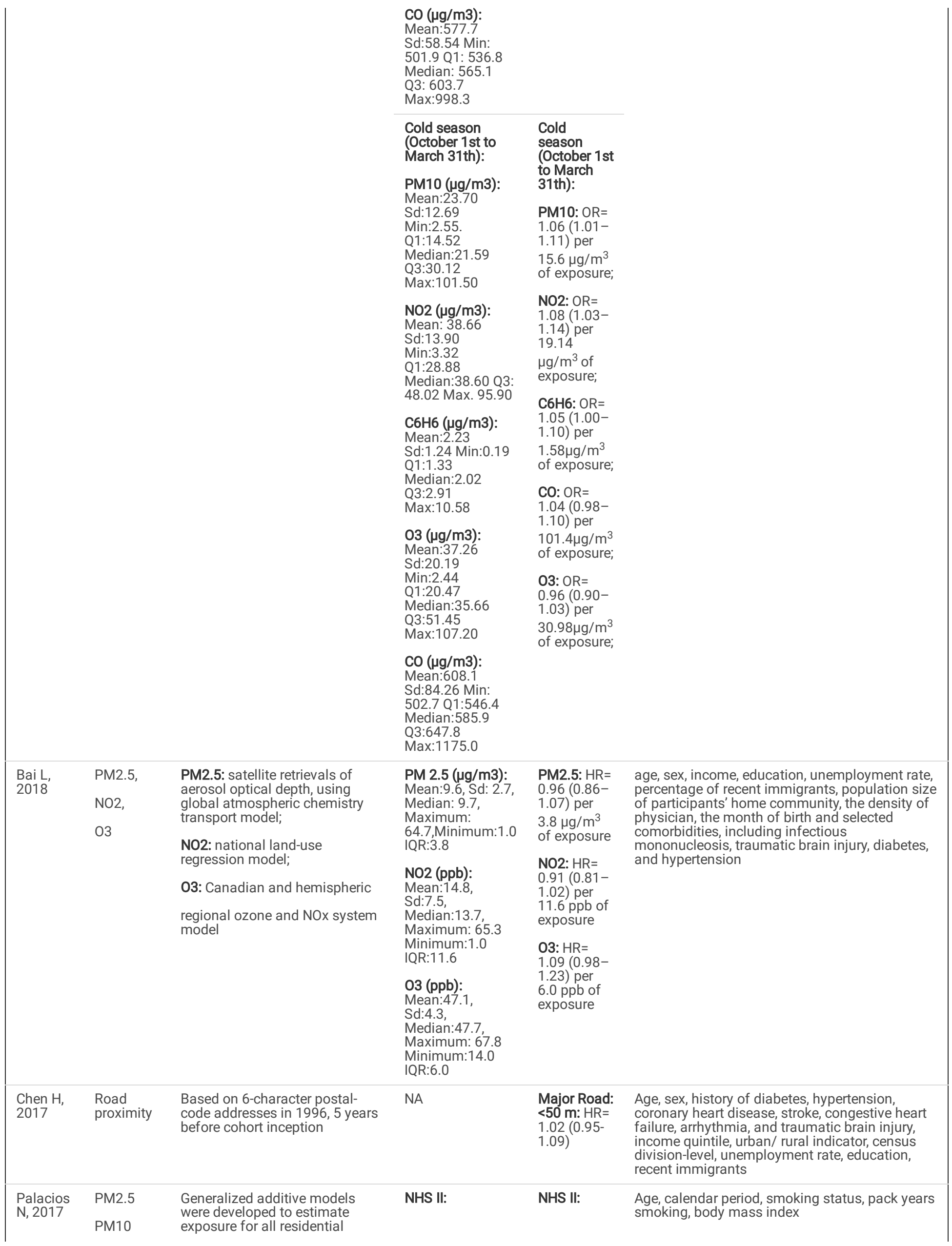




\begin{tabular}{|c|c|c|c|c|c|}
\hline & PM2.5-10 & $\begin{array}{l}\text { addresses using monthly } \\
\text { average PM10 data from } \\
\text { USEPA's Air Quality System } \\
\text { (AQS) }\end{array}$ & $\begin{array}{l}\text { PM2.5: Q1 } \\
\text { Range:1.4-12.1 } \\
\text { Q2 Range:12.1- } \\
\text { 14.0 Q3 } \\
\text { Range:14.0-15.7 } \\
\text { Q4 Range:15.7- } \\
\text { 17.4 Q5 } \\
\text { Range:17.4-74.6 } \\
\text { The distributions } \\
\text { of baseline } \\
\text { characteristics } \\
\text { across quintiles } \\
\text { of } \\
\text { PM 10 and } \\
\text { PM2.5-10 were } \\
\text { similar to that for } \\
\text { PM 2.5. } \\
\text { NHS: } \\
\text { PM2.5: Q1 } \\
\text { Range:0.8-11.9 } \\
\text { Q2 Range:11.9- } \\
\text { 13.8 Q3 } \\
\text { Range:13.8-15.7 } \\
\text { Q4 Range:15.7- } \\
17.6 \text { Q5 } \\
\text { Range:17.6-61.3 } \\
\text { The distributions } \\
\text { of baseline } \\
\text { characteristics } \\
\text { across quintiles } \\
\text { of } \\
\text { PM 10 and } \\
\text { PM2.5-10 were } \\
\text { similar to that for } \\
\text { PM 2.5. }\end{array}$ & $\begin{array}{l}\text { PM10: HR= } \\
1.08(0.89- \\
1.33) \text { per } 10 \\
\mu \mathrm{g} / \mathrm{m} 3 \\
\text { increase } \\
\text { PM2.5: HR= } \\
\text { 1.15 (0.79- } \\
\text { 1.66) per } 10 \\
\mu \mathrm{g} / \mathrm{m} 3 \\
\text { increase } \\
\text { PM2.5-10: } \\
\text { HR=1 } 1.07 \\
\text { (0.80-1.43) } \\
\text { per 10 } \\
\mu \mathrm{g} / \mathrm{m} 3 \\
\text { increase } \\
\\
\text { NHS: } \\
\text { PM10: HR= } \\
0.80(0.51- \\
1.27) \text { per } 10 \\
\mu \mathrm{g} / \mathrm{m} 3 \\
\text { increase } \\
\text { PM2.5: HR= } \\
0.59(0.26- \\
1.33) \text { per } 10 \\
\mu \mathrm{g} / \mathrm{m} 3 \\
\text { increase } \\
\text { PM2.5-10: } \\
\text { HR=0.85 } \\
(0.42-1.74) \\
\text { per } 10 \\
\mu \mathrm{g} / \mathrm{m} 3 \\
\text { increase }\end{array}$ & $\begin{array}{l}\text { (BMI) at age 18, population density, region, tract- } \\
\text { level household income, latitude tier at age 15: } \\
\text { and state-level measures of UV index, median } \\
\text { household income }\end{array}$ \\
\hline $\begin{array}{l}\text { Angelici } \\
\text { L, } 2016\end{array}$ & PM10 & $\begin{array}{l}\text { Obtained from the Regional } \\
\text { Environmental Protection } \\
\text { Agency (ARPA Lombardia) } \\
\text { recordings of daily air pollution } \\
\text { data measured from } 2001-2009 \\
\text { by monitors located at } 53 \\
\text { different sites throughout } \\
\text { Lombardy }\end{array}$ & $\begin{array}{l}\text { PM10 }(\mu \mathrm{g} / \mathrm{m} 3): \\
\text { Min:1.67 p25:22.6 } \\
\text { Mean:42.48 } \\
\text { Std:28.6 p75:54.6 } \\
\text { Max:301.19 }\end{array}$ & $\begin{array}{l}\text { PM10: } \\
R^{a}=1.36 \\
(1.3-1.42) \\
\text { per } 52.93 \\
\mu g / m^{3} \text { of } \\
\text { exposure }\end{array}$ & $\begin{array}{l}\text { day of the week on the date of admission } \\
\text { (from Monday to Saturday), season, day-off, } \\
\text { resident population in each area and with spline } \\
\text { smoothers of temperature and time trend }\end{array}$ \\
\hline
\end{tabular}

a: The maximum effect of PM10 on MS hospitalization which was found for exposure between days 0 and 7 was selected in our research.

Table 3. Publication bias analysis of each pollutants with MS. 


\begin{tabular}{|c|c|c|c|c|c|c|c|}
\hline \multirow[t]{2}{*}{ Source } & \multirow[t]{2}{*}{ Air pollution } & \multicolumn{2}{|c|}{ Heterogeneity test } & \multicolumn{2}{|l|}{ Egger's test } & \multicolumn{2}{|c|}{ Begg's test } \\
\hline & & $\mathrm{I}^{2}(\%)$ & $P$ value & Egger's bias & $P$ value & Begg's z & $P$ value \\
\hline Jeanjean M, $2018(H)$ & \multirow[t]{5}{*}{ PM10 } & \multirow[t]{5}{*}{$0.0 \%$} & \multirow[t]{5}{*}{0.492} & \multirow[t]{5}{*}{-0.77} & \multirow[t]{5}{*}{0.173} & \multirow[t]{5}{*}{-0.49} & \multirow[t]{5}{*}{0.624} \\
\hline Jeanjean M, 2018 (C) & & & & & & & \\
\hline Palacios N, 2017 & & & & & & & \\
\hline Palacios N, 2017 & & & & & & & \\
\hline Angelici L, 2016 & & & & & & & \\
\hline Yuchi W, 2020 & \multirow[t]{4}{*}{ PM2.5 } & \multirow[t]{4}{*}{$36.3 \%$} & \multirow[t]{4}{*}{0.194} & \multirow[t]{4}{*}{0.67} & \multirow[t]{4}{*}{0.691} & \multirow[t]{4}{*}{0.68} & \multirow[t]{4}{*}{0.497} \\
\hline Bai L, 2018 & & & & & & & \\
\hline Palacios N, 2017 & & & & & & & \\
\hline Palacios N, 2017 & & & & & & & \\
\hline Palacios N, 2017ª & \multirow[t]{2}{*}{ PM2.5-10 } & \multirow[t]{2}{*}{$0.0 \%$} & \multirow[t]{2}{*}{0.557} & \multirow[t]{2}{*}{-1.07} & \multirow[t]{2}{*}{ NA } & \multirow[t]{2}{*}{-1.00} & \multirow[t]{2}{*}{0.317} \\
\hline Palacios N, 2017 b & & & & & & & \\
\hline Jeanjean M, $2018(H)$ & \multirow[t]{2}{*}{ Benzene (C6H6) } & \multirow[t]{2}{*}{$66.4 \%$} & \multirow[t]{2}{*}{0.084} & \multirow[t]{2}{*}{-3.56} & \multirow[t]{2}{*}{ NA } & \multirow[t]{2}{*}{-1.00} & 0.317 \\
\hline Jeanjean M, 2018 (C) & & & & & & & \\
\hline Jeanjean M, $2018(H)$ & $\mathrm{CO}$ & $68.6 \%$ & 0.074 & -5.34 & NA & -1.00 & 0.317 \\
\hline Jeanjean M, 2018 (C) & & & & & & & \\
\hline Yuchi W, 2020 & NO2 & $64.9 \%$ & 0.036 & -1.52 & 0.530 & -0.68 & 0.497 \\
\hline Jeanjean M, $2018(H)$ & & & & & & & \\
\hline Jeanjean M, 2018 (C) & & & & & & & \\
\hline Bai L, 2018 & & & & & & & \\
\hline Jeanjean M, $2018(H)$ & 03 & $84.3 \%$ & 0.002 & 1.06 & 0.855 & -0.52 & 0.602 \\
\hline Jeanjean M, 2018 (C) & & & & & & & \\
\hline Bai L, 2018 & & & & & & & \\
\hline Yuchi W, 2020 & Road proximity & $78.8 \%$ & 0.030 & 2.86 & NA & 1.00 & 0.317 \\
\hline Chen H, 2017 & & & & & & & \\
\hline
\end{tabular}

a: NHS II, Nurses' health study II; b: NHS, Nurses' health study; H: hot season; C: cold season

\section{Figures}




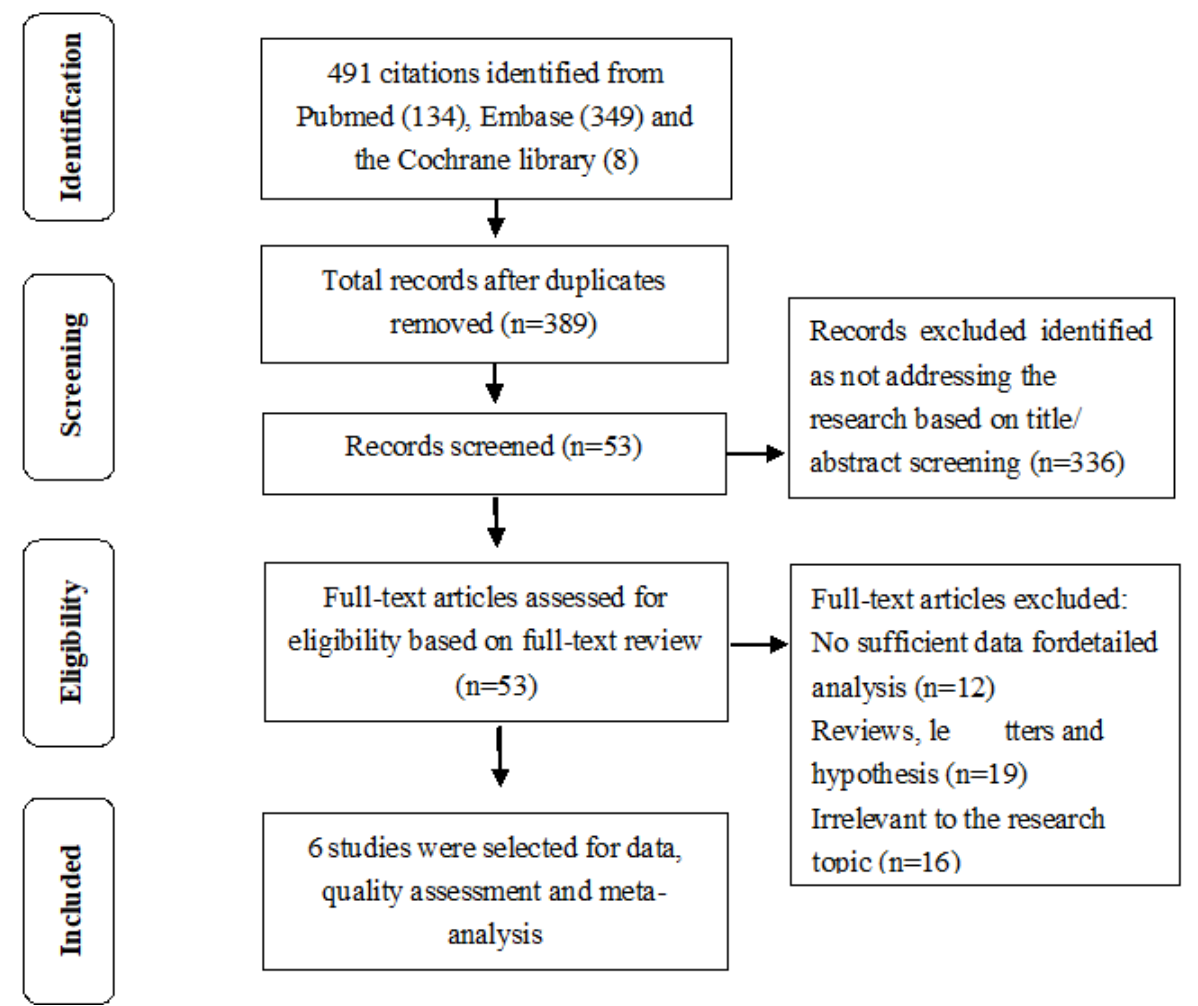

Figure 1

Flow diagram of searching articles. We excluded duplicate publication, unmatched purposes, review, letters, hypothesis etc. At last, 6 studies were included in our present study.

Study
ID


Figure 2

Forest plots for the pooled risk estimate of PM2.5, PM2.5-10, and PM10 exposure (per $10 \mu \mathrm{g} / \mathrm{m} 3$ increment) with MS.

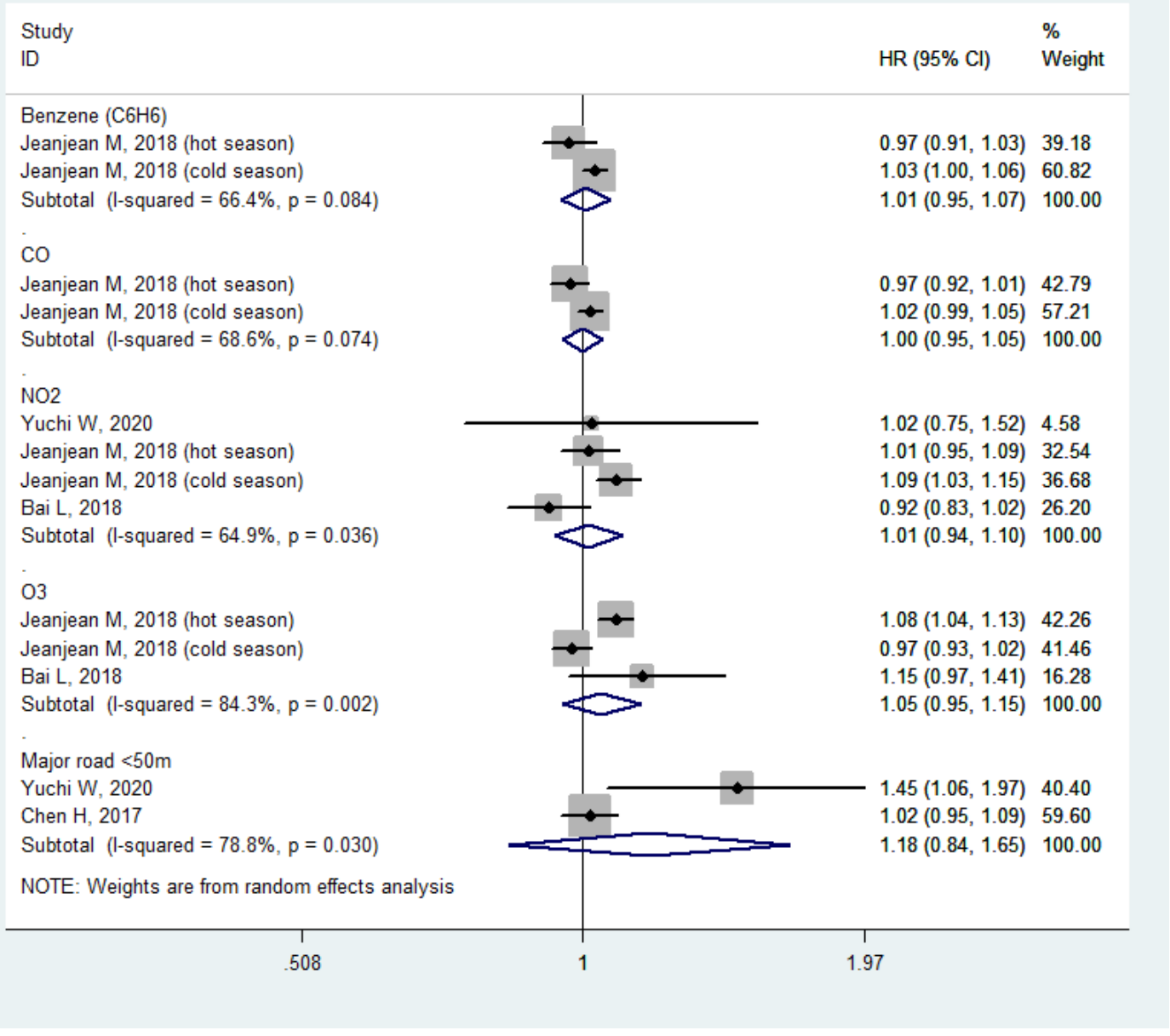

\section{Figure 3}

Forest plots for the pooled risk estimate of NO2 (per 10 ppb increment), 03 (per 10 ppb increment), CO (per $50 \mu \mathrm{g} / \mathrm{m} 3$ increment), C6H6 (per $1 \mu \mathrm{g} / \mathrm{m} 3$ increment), and Road proximity with distance from major road $<50 \mathrm{~m}$ exposure with MS.

\section{Supplementary Files}

This is a list of supplementary files associated with this preprint. Click to download.

- Tables1.doc

- Tables2.doc 